\title{
Local Pathology Review
}

National Cancer Institute

\section{Source}

National Cancer Institute. Local Pathology Review. NCI Thesaurus. Code C126371.

Microscopic examination of tissue specimen(s) by a pathologist in the local institution where a patient had a procedure performed, using local standardized methods and criteria. 